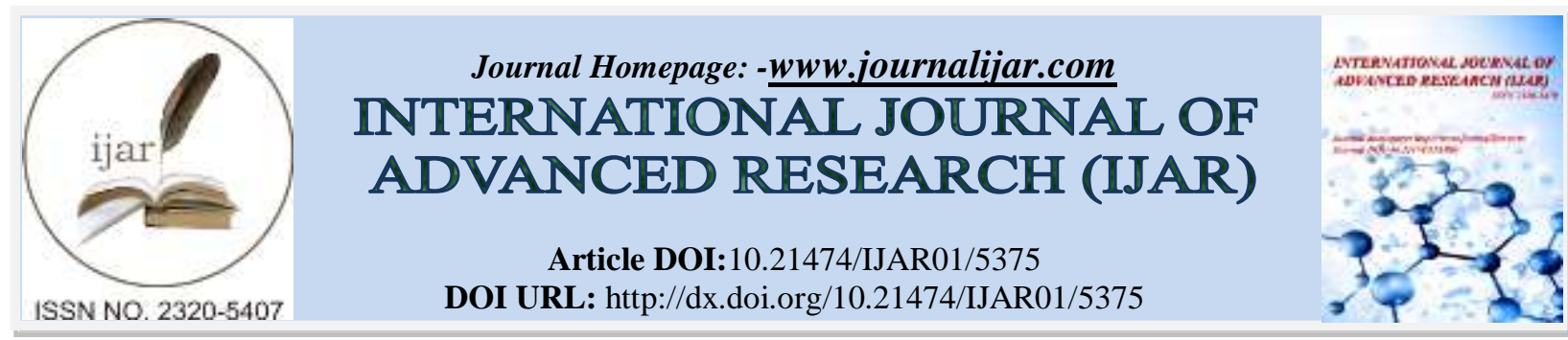

RESEARCH ARTICLE

\title{
RECONSTRUCTION ON THE REGULATION GOVERNING THE NON-PRIMARY WEAPON SYSTEM AS AN EFFORT TO ACHIEVE LEGAL PROTECTION FOR THE INDONESIAN MILITARY BASED ON THE LEGAL CERTAINTY AND DIGNIFIED JUSTICE PRINCIPLES.
}

Said Gunawan ${ }^{1}$, Prof. Dr. Teguh Prasetyo SH. M. Si ${ }^{2}$ and Dr. Hj. Anis Mashdurohatun S. H. M. Hum ${ }^{3}$.

1. Doctoral Student at the Faculty of Law Sultan Agung Islamic University, Semarang Central Java-Indonesia.

2. Faculty of Law Universitas Kristen Satya Wacana Salatiga Central Java-Indonesia) and Recently has been Appointed by the President of the Republic of Indonesia as the Commissioner for the Republic of Indonesia's Court of Ethichs for the General Election Organizers.

3. Faculty of Law Sultan Agung Islamic University, Semarang Central Java-Indonesia.

\section{Manuscript Info}

(.........................

Manuscript History

Received: 09 July 2017

Final Accepted: 11 August 2017

Published: September 2017

Key words:-

Reconstruction, Regulation, Non-

Primary Weapon System, Certainty and

Justice, Legal Protection.

\begin{abstract}
This study aims to reconstruct principles of law governing the nonprimary weapon system to provide a legal protection for the member of the Indonesian military (TNI) based on the values of certainty and justice. The study has found: (1) the principle of non-primary weapon system is subject to Law Number 34 of 2004 on TNI, especially the principle of civilian supremacy. There are also regulations which are having the same character, namely Article 149 of the Indonesian Military Criminal Code (KUHPM) and the Decree of the Commander in Chief of the Army Number SKEP/346/X/2004 but unfortunately the Decree is valid only internally. These regulations have created, however, uncertainties and injustice. (2) Lacunae, the weakness in the principle governing the TNI's non-primary weapon system, has violated legal certainty and justice; law enforcement is unfair, since it is enforceable only for members of the TNI and binding internally, while at the same time civilians who abusing the non-primary weapon system are not subject to legal proceedings, let alone criminal sanctions; therefore no equality before the law. In the reconstruction, the law and its sanctions governing the abusers (both the military and the civilians) of non-primary weapon system has been recommended. There must be a stipulation added to Article 149 KUHPM: "the non-primary weapon system misuse by civil society is subject to the existing laws and regulations including the Criminal Code, the Civil Code and other specific laws governing economic crimes; and among other things are regulations such as copyrights, trademark, trade secret and patent.
\end{abstract}

Copy Right, IJAR, 2017,. All rights reserved.

\section{Introduction:-}

Recently, in Indonesia resurface issues which had seldom appeared as controversial in the past. One of the issues has arose in the era before and towards (transition era) the reform era in Indonesia. The issue is the using of military equipment apart from weapon or here is termed as the non-primary weapon system of the Indonesian Army by the 
civilians. Ranging from simple things, the use of a non-primary weapon system such as attributes are masive by the civilians on numerous occasions and in number of places. Sticker (window clings), shirt, pants, jackets, helmets, eye-glasses, shoes, military uniforms and many more, including the property rights (intellectual property rights) such as patent are used, and even claimed as own by the civilian legal subjects. A wide range of clothes wearing by civilians on the streets can be easilly encountered, even being sold without license nd restrain to the public. Military brands (trade secrets) are mostly used by citizens or civil society (non-combatan).

Not only the general public whom may be blamed for that. President of the Republic of Indonesia, Joko Widodo (Jokowi) in fact, in several occasions (a number of ceremonies with the Indonesian Military or TNI) has used attributes (insignia) and military uniforms. One would then wonder that if the President could freely used the nonprimary weapon system, it then becomes a question, why the other civilian is prohibited in using them. This urgently legal question has been waiting to be answered or to be resolved by a study of this kind.

Refers to the meaning of the concept of non-primary weapon system are also to include grade of military or the sign of military ranks (insignia). A number of the President Jokowi's aides, both inside the President's Cabinet, or occupy the offices outside the Ministry are still easily seen using the military insignia pinned, or annexed before their name; although in fact they have retired, or rather have become citizens or civil society (civil society).

Facing the situation of the use of military ranks as such, there is possibility for a soldier and an officer or a member of the armed forces, for example an actively promoted Lieutenant General, when meeting with a retired Lieutenant General of the Indonesian Army (the civilian), because he or she is still using the military rank of Lieutenant General, the Lieutenant General (the official one), and active military personel, might feel really uncomfortable. In the language of the legal issue of this research, the Lieutenant General of the right one (the active soldier or the official military officers), may feel "not sure" about his or her existence as active TNI soldiers, due to the use of the non-primary weapon system by the retired Lieutnant General.

So far it has been proposed a logic expressed by the head of Department of the Indonesian Air Force (Kadispenau), Marsekal Pertama TNI Dwi Badarmanto, that besides breaking the law, the use of military attributes (non-primary weapon system) by civil society, in fact, very dangerous to themselves as civilians, say for example in case of there is armed conflict in the Country. Therefore, as expressed above, the theoretical or philosophical study of the law on this problem is important to take in order to solve the problems as mentioned above.

\section{Military-Civilian Relations:-}

Theoretically, the problem as mentioned above could be analysed philosophically using the civil-military relations perspective, but in terms as legal subject it could be placed under the perspective stipulated in the Republic of Indonesia's Act No. 34 of 2004 on TNI. It has been stipulated in the Act that the President is the civilian. Under the perspective of the principle of the civilian supremacy, the position of President of the Republic of Indonesia is above the Commander-in-Chief. That is the clear deontologi of the Act No. 34 of 2004 on TNI. This deontologi of laws is not views without any basis.

Explicitly by the Act No. 34 of 2004 on TNI it has been formulated firmly, that the TNI is subject to the principle of civil supremacy. It is the principle of law in the Pancasila Legal System. This has mandatory been understood as giving a clear signal that civilians must not use the military attributes (the non-primary weapon system). Since, by its nature or its ontology of the civil-military relation, if civilian uses military attributes, then consequently at the time of the use of those attributes, the civilian would have been associated as the military. It can be seen as a violation of the basic law which demands civilian supremacy in the civil-military relation; or a violation of the laws.

The background of the basic laws that dictated civil supremacy, which was formulated in the legislation, does not necessarily to demean the degree of the military vis a vis the civilian. The stipulation of the principle is instead aims at affirming that there is a difference from the point of view of law between the civilians on one side compared to the military on the other side. In order to ascertain the settings in Indonesian legislation as mentioned above, in the section regarding Consideration of Act No. 34 of 2004 on TNI it was formulated that: "...the TNI was built and developed professionally ... values and principles ..., civil supremacy ...". 


\section{A Comparative Law Perspective:-}

To understand better the juridical character as already stated in Indonesian law expressed in the Act No. 34 of 2004 on TNI a comparative study could be made with the nature of civilian supremacy known in the United States, for example. Civilian supremacy in Act No. 34 of 2004 on TNI has a meaning adapted to the historical development of the soul of the nation (Volksgeist) Indonesia. While the meaning given to the concept of civil supremacy in the American Constitution is adapted to the development of the soul of the nation (Volksgeist) United States.

In the history of the development of Indonesia, civil supremacy is to include different meanings. The variation of the meaning of the civil supremacy has been changed with the definition of the legal provisions set up in Article 10 of the Constitution of the Republic of Indonesia Year 1945 (UUD 1945). Regulated in Article 10 the Constitution of 1945 that: the President (the civilian) hold the highest power over the Army, Navy and Air force.

The formulation of this provision means that the President is an agency of the supreme civil authority, under the law, of course. The next commanders in the military under the Commander in Chief of the military were the heads of the armed forces consisting of three forces, namely Army, Naval and Air forces. In this term, the meaning of civilian supremacy according to the Article 10 of the 1945 Constitution, in other words, can only be realized if the President is a civilian ruler, while the military commanders and its Commander-in-Chief are under the highest authority or civil supremacy in the hands of the President.

In this research the military-civil relationship is depicted under the issue of the law governing the use of the military attributes by civilians. In such a law, by its nature, the position of the President according to the Article 10 of the 1945 Constitution have to be understood as the President should not be using military symbols, particularly in terms of the research discussed in this dissertation, i.e. non-primary weapon system. For, as has been expressed above, if the (military symbols) are used by the President which is a civilian, then the position of the President will be transformed from the vertical relationships in the civil-military relations to the equivalent (coordinate), with the military.

Ideally, the concept of civilian supremacy in the civil-military relationship under the law is a vertical one or is subordination, not co-ordination. In a relationship that is sub-ordinate, one party (the President of the (civilian) is higher than the other (military). Within this perspective, the higher position is not allowed to use the symbols of the lower party in the hierarchy. Otherwise, there would be no longer any supreme or supremacy in the civil-military relations. Since, if the supreme uses attributes that are lower than the attribute, then the nature of that civilian supremacy will be lost; and replaced with the rule of the military, unless the law regulating otherwise.

In the course of history, Article 10 of the 1945 Constitution indeed had given the meaning that the President is the Supreme Commander of the armed forces of the Republic of Indonesia. The example for such a definition occurred in the age of the Old Order (President Sukarno). So did the unheard of in the days of the New Order (President Soeharto). At those time President Sukarno and President Suharto, wearing military symbols, while at the same time claimed that both are the Commander-in-Chiefs of the Indonesian Army.

It is almost similar to that happened in Libya, for example, with M. Gadaffi. The same situation has also happened in Iraq, with Sadam Husein; or civil leaders in countries of Africa, such as Idi Amin, the leader of the Communist Party in North Korea and others. So, in the reign of President Sukarno and President Suharto, civil supremacy concept for both Presidents, and also for the men in the street, probably have a difference substance, with meanings that are supposed to be according to the law, as expressed above.

Furthermore, in addition to the juridical background described above, there is also a juristic-sociological background (lay-man's view or the view of the men in the street). In this view, the term commander-in-chief can also be associated with the formulation of the provisions of Article 11 paragraph (1) of the 1945 Constitution. In the Article 11 paragraph (1) of the 1945 Constitution, it is expressed that the President with the approval of the House of representatives (DPR) declared war. The meaning of the civil supremacy in the Article 11 paragraph (1) of the 1945 Constitution has been referred to the nature of the civilian supremacy understood when President Sukarno and President Suharto came to power. Problem, in the view of the men in the street which then followed, was all members of the House who is also involved in the mandate of Article 11 paragraph (1) of the 1945 Constitution (i.e. because of the agreement should be achieved jointly between the President and the Parliament, then they (all members of the House) can use the attributes of the military, and can share the meaning of Commander in Chief). 
This led to chaos in the constitutional meaning. In fact, the practical implications behind such understanding can occur not because of the Declaration of war by the Commander of the Indonesian Armed Forces, but the Declaration of war that can only be made by the holder of the supreme power over the Army, Navy and Air force.

The opposite situation occurs in the United States an in the United Kingdom for example. In the United Kingdom, Prime Minister of the United Kingdom is in fact the Chief Executive of the country's, and it is stated by the Constitution (the Common Law). However, the Prime Minister in the United Kingdom does not hold status as Commander in Chief, but instead there is an effective monitoring and control by civilian (civilian control), in this case the civilian supremacy as desired in the United States, as well as explicitly formulated in Indonesia in Act No. 34 of 2004 on TNI has been changed very effectively.

\section{Warning to the Reform of the Civil-Military Relations:-}

Warning suggested by the head of Department of the Indonesian Air Force (Kadispenau), Marsekal Pertama TNI Dwi Badarmanto as stated above, was not intended for the civilians which use the military attributes that they may damage the ideals of reformation for the TNI, but it was also intended to remind the civilians who holds the power of Government in addition to the military, the Executive Board of a political party. The President, for example is part of civil society, and including in it part of the civilian supremacy, as stipulated in Act No. 34 of 2004 on TNI. Moreover, President Joko Widodo is having background as a Carpenter, and furniture businessman. He never been the TNI soldiers. If the President uses the military uniform, one may wonder is there ever any carpenters or businessmen also a military. As it has been a general knowledge that the military has just having skills as advanced by Lawswell, i.e. the management of violence. It looks awkward when the carpenters or businessmen is considered as military; in the civil-military relations according to the Indonesian law.

Furthermore, one would argue that following the logic proposed by the head of Department of the Air Force (Kadispenau), Marsekal Pertama TNI Dwi Badarmanto as set forth above, then the use of uniforms and military attributes by the President, is not only aginst the law, i.e. the principle of civilian supremacy, but it could also endanger the President himself. The concept of "endangering themselves," in this case can be meaningful in denotative, but would also contain the meaning of connotative.

The concept of harm in denotative meaning is: if the President used the uniforms and the non-primary weapon system then it could attribute that the President may think that he has his own forces. Whereas in the meaning of conotatif it can mean: as expressed above, if the President uses military attributes, then he (the President) endanger civil supremacy that is in "his grasp". The President is confusing, military affairs and civil affairs. One can only assume that, if that happens, there is a breach of regulations and the Constitution.

Not only the President and citizens in General, head of Department of the air force, Marsekal Pertama TNI Dwi Badarmanto also suggests some sort of complaint. That, in our society there is a duplication of the use of uniforms and military attributes by civilians as happened this time. The duplication that occurs, for example, in such agencies like Kemenhub, Kemenhum, Polsuska and Ham. According to the head of Department of the air force Explanation (Kadispenau), Marsekal Pertama TNI Badarmanto, Dwi, at least duplication impact less well among the TNI AU/TNI internal and external community.

The following statement of the head of Department of the Air Force, First Marsekal of the TNI, Dwi Badarmanto reads:-

Among the internal Air Force soldier/TNI, the use of uniforms and military attributes by civil had "hurt" the hearts of the soldiers of the Indonesian Air Force. (Tort issues negatively or omission) the use of uniforms and attributes that will eventually lower the morale of the soldiers, because there is no longer the pride against uniforms and attributes that she wore, because it makes no difference with civilian agencies. The impact for external, use of uniforms and attributes the duplicating of the military by civilian may give rise to a negative image of soldiers or military institutions.

TNI's loss can occur when civil society who use uniforms and military attributes do stray or acts that are not acceptable in the community. There is the impression, in the expression of head of Department of the Air Force, Marsekal Pertama TNI Dwi Badarmanto that, if civilians use non-primary weapon system, and bring about benefits, that will lifted the dignity of members of TNI, then there's a justification or forgiving, and this seems to became a general principle once known in Indonesian criminal law, while the State embraced the principle of legality. It has 
been put forward above that the principle of legality is thus a foundation of the civilian supremacy. The principle of legality in general requires the inclusion of definitively and expressly rule in the legislation for something becomes law. It has been made possible by Article 149 of the Book Law on Military Criminal Law (KUHPM). Set forth in article 149 KUHPM that:

The military including the army which has been prepared for war is prohibited without written permission from or on behalf of the officer who has the right to: sell, swap, give away, mortgaged, borrow, or store, or remove something of the goods given by the State to him or to the other military, for using such goods including military equipment, clothing is threatened with imprisonment of a maximum of five years.

The Section 149 of the KUHPM as presented above seems to suggest that clothing and military equipment (nonprimary weapon system) can only be lent to (military) and there is an understanding that it could be extended to the civilian. Bear in mind that, according to the principle of legality, through a mechanism of license, the officer is entitled, then the non-primary weapon system can be loaned, in this case something in the goods given by the State, to the other, the military, and also extended to civilians. So, the use of uniforms and military attributes by civilians so far encountered in the community widely, including those expressed above, which is also used by the President, is something that is legitimate.

\section{Conclusion:-}

The principle of law governing the non-primary weapon system is subject to Law No. 34 of 2004 on TNI, especially the principle of civilian supremacy. These principles are only included in the Considerations section or under consideration only. Not specifically regulating the general provisions at the Bodies Law, 34 of 2004 . There are also arrangements with the same character, namely Article 149 of the Indonesian Criminal Code and the Decree of the Commander of the TNI. SKEP/346 /X/2004 are both valid only internally. This creates a regulatory uncertainties.

Weaknesses in the TNI's non-primary weapon system regulation principles are the existence of legal vacuum, have caused violation on the principle of legal certainty and and justice; law enforcement was biased (unfair), only enforced upon the members of the military while the civilians who have abused the non-primary weapon system were escaping proceedings, and especially no criminal sanctions could be imposed upon; this is the fact that there has been no equality before the law. The legal structure of the jurisdiction of the military laws and court has aimed at the military personel alone. While the legal culture for the settlement is only through litigation. This becomes an obstacle to legal protection for TNI members and organizations based on the value of certainty and dignity of justice.

Reconstruction of values in the governing principles of law of non primaryweapon system shall be liable to sanctions, while the reconstruction of legal norms must reform with the addition of paragraph (2) to Article 149, namely: the non-primary weapon system misuse by civil society have to be referred to the prevailing laws and regulations, among other things are the Indonesian Criminal Code, Civil Code and those laws on the Economic Criminal Act (such as copyright, trademark, trade secret and patent.

In order to have a balance between law enforcement in the form of sanctions imposed on TNI soldiers who transfer the use of non-primary weapon system to civilian parties and non-primary weapon system misuse by civil parties, it is necessary to regulate in general the offense of non-primary weapon system use in general offense, so that both the military and the civilian parties who abuses the non-primary weaponsystm may be subject to the similar criminal procedures and sanctions on the basis of the same legal provisions. This is a form of value reconstruction. For the reconstruction of rules, then when the lawmaking are govern offense of abuse of non-defense equipment by the civil experiencing difficulty then in the short term, Act No. 34 of 2004 on the TNI can be changed, even if indeed it can be said already contains a formula strongly; that the military is subject to the legal principle of "supremasi sipil(civil supremacy)".

It is suggested that there should be a preventive arrangement of non-primary weapon system users who follow the principle or principle of civil supremacy, which is regulated in a special law or amend the UU-TNI. Need to be formulated in the Elucidation of Article 7 Paragraph (2) b, in order that on the basis of TNI duty other than war, the TNI can assist the Government in monitoring or the control of the use of non-primary weapon system. The most concrete suggestion, concerning the issue of legal vacuum in Article 149 of the Criminal Code, it is necessary to add paragraph (2) to become part of the formulation of Article 149 of the Criminal Code that: non-alutsista misuse by 
civil parties refers to the applicable laws and regulations, such as the Criminal Code and provisions concerning IPR, especially Patent.

Given the urgency of the demands of justice (equality before the law), so that both the civilian and military of abusing non-primary weapon system obtain treatment (penal sanctions) are the same, then in a period of legal vacuum, it is suggested to the Government to have the Patent on non-defense equipment, so that any person abusing non-alutsista can be intimately connected with the applicable Patent regime.

At the theoretical level, the study that has been conducted on the use of non-alutsista has added a new finding that enriches the study of military law, in relation to civil-military issues from the legal point of view. At the practical level, this study has succeeded in finding a solution of dignified and equitable dignity so that the regulation on the use of non-primary weapon system should use a general offense, compared to that used so far, that is arrangement as a special crime in the Pancasila Legal System.

\section{Bibliography:-}

1. AnisMashdurohatun, 2016, Mengembangkan Fungsi Sosial Hak Cipta Indonesia (Suatu Sudi pada KaryaCipta Buku), UNS Press, Surakarta.

2. Endang Prasetyowati, 2010, Metode Penelitian Hukum, CetakanPertama, Fakultas Hukum Universitas 17 Agustus 1945, Surabaya.

3. Teguh Prasetyo dan Abdul Halim Barkatullah, 2011, Ilmu Hukum dan Filsafat Hukum Studi Pemikiran Ahli Hukum Sepanjang Zaman, Cetakan Keempat, PustakaPelajar, Yogyakarta.

4. ----------,2012, Filsafat, Teori, dan Ilmu Hukum Pemikiran Menuju Masyrakat yang Berkeadilan dan Bermartabat, Cetakan Kesatu, RajaGrafindo Persada, Jakarta.

5. Teguh Prasetyo dan Arie Punomosidi, 2014, Membangun Hukum Berdasarkan Pancasila, Nusamedia, Yogyakarta.

6. Teguh Prasetyo, 2010, Hukum Pidana, EdisiRevisi, RajaGrafindo Persada, Jakarta.

7. ---------, 2013, Hukum dan Sistem Hukum Berdasarkan Pancasila, Edisi Kesatu, Media Perkasa, Yogyakarta.

8. -------, 2015, Keadilan Bermartabat, Perspektif Teori Hukum, CetakanPertama, Nusa Media, Bandung. 